\title{
Yield and Physiological Response of Tomato to Various Nutrient Managements under Container Grown and Drip Irrigated Conditions
}

\section{Etissa $\mathrm{E}^{1 *}$, Dechassa $\mathbf{N}^{2}$ and Alemayehu $\mathbf{Y}^{1}$}

${ }^{1}$ Ethiopian Institute of Agricultural Research, Addis Ababa, Etiopia

${ }^{2}$ College of Agriculture and Environmental Sciences, Haramaya University, Etiopia

\begin{abstract}
Two field experiments were conducted to study fruit yield and physiological responses of field grown tomato. The first experiment was conducted with container grown during rainy season by combining three factors namely, two levels of $\mathrm{N}\left(0\right.$ and $25 \mathrm{~kg} \mathrm{~N}$ ha-1), and two levels of $\mathrm{P}\left(0\right.$ and $\left.23 \mathrm{~kg} \mathrm{P}^{-1}\right)$ fertilizers and with six locally available media mix ratios (MR). The experiment was laid down on CRBD in a factorial arrangement and replicated three times. The second experiment was conducted under drip irrigation during hot dry season with three levels of daily irrigation applications: full irrigation, $80 \%$ and $60 \%$ of daily ETc irrigations. Data on marketable, unmarketable and total fruit yield were recorded and some physiological responses: quantum yield, leaf chlorophyll content and fluorescence, and stomatal conductance were assessed from sample plant leaves using various sensors. The results of container grown experiment indicated that use of combinations of starter $N$ and MR showed a significant effect $(P<0.05)$ on the marketable fruit yield, similarly use of media mixtures had highly significant $(P<0.01)$ influence on the unmarketable fruit yield and finally use of media mix ratio showed a highly significant effect $(P<0.01)$ on the total fruit yield of container grown tomato. MR3 yielded the highest total fruit yield while MR6 gave the lowest total fruit yield. Application of starter $\mathrm{N}, \mathrm{P}$ or media mix did not bring any combined effect $(\mathrm{P}<0.01)$ on the leaf chlorophyll content. However, application of starter $\mathrm{N}$ caused a highly significant $(\mathrm{P}<0.01)$ effect on leaf quantum yield. The results of drip irrigated experiment indicated that use of various irrigation depth brought a significant $(P<0.01)$ effect on the marketable yield of tomato. The highest fruit yield was recorded in response to full irrigation, while the lowest marketable fruit yield was recorded from $60 \%$ of full irrigation. Irrigation depth significantly $(P<0.01)$ affected the tomato leaf chlorophyll content. The highest irrigation level increased leaf chlorophyll content and lowest irrigation depth reduced leaf chlorophyll content. Irrigation depth brought significant $(P<0.01)$ effect on the stomatal conductance as irrigation depth decreased, leaf stomatal conductance was highly reduced. Measuring quantum yield, leaf chlorophyll content, and fluorescence and stomatal conductance of tomato plant there is indicated direct relation with yield performance that would give instant improvement of management practices of the crop. Thus further research is required to fine tune and use of this physiological response with the crop yield.
\end{abstract}

Keywords: Leaf chlorophyll; Leaf fluorescence; Stomatal conductance; Tomato

\section{Introduction}

Tomato (Lycopersicum esculentum M.) is grown under various production conditions such as under furrow irrigated and under rainfed in open field, on containers of variable sizes and media mixes in home gardens, under drip irrigated throughout the year in Ethiopia [1]. All smallholder growers in the Central Rift Valley of Ethiopia cultivate tomato using furrow irrigation in open field, where as commercial and semi-commercial growers cultivate in the protected structures $[2,3]$. The majority of tomato production in the country comes from furrow irrigated open field cultivated almost throughout the year except during the rainy season the production is lower due to diseases pressure.

Based on many literatures, plant physiological parameters such as leaf fluorescence, leaf quantum yield, leaf chlorophyll contents and stomatal conductance are among indexes that would provide indirect estimation of plant growth, development and yield [4-6].

Light energy is absorbed by chlorophyll, carotenoids and other pigment molecules present in the photosynthetic antenna molecules present in the thylakoid membranes of green plants [6-9]. Chlorophyll fluorescence is the light re-emitted by chlorophyll molecules during return from excited to non-excited states during the light absorption and used as indicator of photosynthetic energy conversion in higher plants [4]. Excited chlorophyll dissipates the absorbed light energy by driving photosynthesis (photochemical energy conversion), as heat in non-photochemical quenching or by emission as fluorescence radiation. As these processes are complementary processes analysis of chlorophyll fluorescence is an important tool in plant research with wide spectra of applications [4].

For light to be active in leaf photosynthesis it must be absorbed; light energy that is absorbed can be dissipated in one of three ways A) lost as heat, B) re-irradiated as red light (fluorescence) or C) used in photosynthesis (photochemistry). These three processes are competitive $[4,9]$. That is, an increase in the efficiency of one process will decrease the yield of the other two. Even though chlorophyll fluorescence is only about 1 to $2 \%$ of the total light energy absorbed; we can use the fluorescence signal of a leaf to estimate rates of photosynthesis (photochemistry) and heat dissipation. Generally, chlorophyll fluorescence production is inversely related to photosynthesis, except when non-photochemical quenching of fluorescence (thermal dissipation) occurs [9]. Under stress or in moderate to high irradiance conditions, plant tissues increase heat production to dissipate excess energy (Anon.). This tends to decrease fluorescence emission, at

*Corresponding author: Etissa E, Ethiopian Institute of Agricultural Research Addis Ababa, Etiopia, Tel : + (251) 0255530324/915321046; Fax: + (251) 025553 0106/025 553 0325; E-mail: edossa.etissa@gmail.com

Received July 13, 2016; Accepted August 24, 2016; Published August 31, 2016

Citation: Etissa E, Dechassa N, Alemayehu Y (2016) Yield and Physiologica Response of Tomato to Various Nutrient Managements under Container Grown and Drip Irrigated Conditions. Irrigat Drainage Sys Eng 5: 171. doi: 10.4172/21689768.1000171

Copyright: ( 2016 Etissa E, et al. This is an open-access article distributed under the terms of the Creative Commons Attribution License, which permits unrestricted use, distribution, and reproduction in any medium, provided the original author and source are credited. 
least in the initial and intermediate stages of stress. Therefore, the relative balance between the three major dissipation mechanismsphotosynthesis, heat production, and chlorophyll fluorescence emission-ultimately determines the actual pattern of response observed for fluorescence [9].

Chlorophyll $a$ fluorescence from light excited vegetation emanates in specific red and far-red spectral regions, and is produced by photosystems I and II (PSI and PSII) which are pigment- protein complexes involved in the initial stages of photosynthesis [4,9]. The steady-state fluorescence, known to be highly responsive to changes in environmental conditions, is widely used as indicator of plant photosynthetic function, and can be used in the early, pre-visual detection of physiological strain. Early detection may facilitate remedial action before survival, growth and productivity are constrained, and may help to forecast long term resource quality [9].

Leaf quantum yield is light reactions of photosynthesis Taiz and Zeiger [5] quantum yield measures light that has actually been absorbed. The quantum yield for a particular process can range from 0 (if that process does not respond to light) to 1.0 (if every photon absorbed contributes to the process). Photosynthetic rate is often expressed as number of molecules of $\mathrm{CO}_{2}$ fixed or $\mathrm{O}_{2}$ evolved per unit leaf area per unit time (for example, $\mu \mathrm{mol} \mathrm{CO} \mathrm{m}^{-2} \mathrm{~s}^{-1}$ ), while quantum yield is expressed as number of molecules of $\mathrm{CO}_{2}$ fixed or $\mathrm{O}_{2}$ evolved per photon absorbed [10]. Taiz and Zeiger described that in functional chloroplasts kept in dim light, the quantum yield of photochemistry is approximately 0.95 , the quantum yield of fluorescence is 0.05 or lower, and the quantum yields of other processes are negligible [5]. The vast majority of excited chlorophyll molecules therefore lead to photochemistry.

The most active photosynthetic tissue in higher plants is the mesophyll of leaves. Mesophyll cells have many chloroplasts, which contain the specialized light-absorbing green pigments, the chlorophylls. In photosynthesis, the plant uses solar energy to oxidize water, thereby releasing oxygen, and to reduce carbon dioxide, thereby forming large carbon compounds, primarily sugars. The absorption spectrum of chlorophyll $a$ indicates approximately the portion of the solar output that is utilized by plants. The photosynthetic pigments absorb the light that powers photosynthesis [5].

$\mathrm{CO}_{2}$ diffuses (stomatal conductance) from the atmosphere into leaves-first through stomata, then through the intercellular air spaces, and ultimately into cells and chloroplasts [5]. In the presence of adequate amounts of light, higher $\mathrm{CO}_{2}$ concentrations support higher photosynthetic rates. The reverse is also true; that is, low $\mathrm{CO}_{2}$ concentration can limit the amount of photosynthesis.

The quantum yield is another important parameter of the light reactions of photosynthesis Taiz and Zeiger described as the quantum yield of photosynthesis $(\phi)$ is defined as follows [5]:

$$
\phi=\frac{\text { Number of photochemical products }}{\text { Total number of quanta absorbed }}
$$

The quantum yield for a particular process can range from 0 (if that process does not respond to light) to 1.0 (if every photon absorbed contributes to the process). Thus estimation of any one or all of these parameters from growing plants could provide an estimation of the biomass yield of crop plants under consideration. The objectives of these experiments were to assess physiological and yield response of tomato under various nutrient managements under container grown and drip irrigated conditions at Melkassa.

\section{Materials and Methods}

Two experiments were conducted at Melkassa Agricultural Research Centre; Central Rift Valley of Ethiopia, the first experiment was with container grown tomato conducted during rainy season and the second experiment was with drip irrigated tomato during the hotdry season.

\section{Container grown tomato}

The first experiment was conducted during the rainy season using container grown tomato. Three factors, namely, media proportions (mixes); and supplementary $\mathrm{N}$ and $\mathrm{P}$ applications rates were combined factorially. The treatments consisted of two levels of inorganic $\mathrm{N}(0$ and $25 \mathrm{~kg} \mathrm{~N} \mathrm{ha}^{-1}$ ) fertilizer, and two levels of inorganic P (0 and 23 $\mathrm{kg} \mathrm{P} \mathrm{ha}{ }^{-1}$ ) fertilizers and with six media mix ratios. Locally available decayed animal manure and livestock droppings were collected and mixed with sand and topsoil at various proportions. Field soil (top soil), well decomposed manure, sand were mixed forming six treatment combinations (v/v) such as 1) 6:0:0, 2) 5:1:1, 3) 4:1:1, 4) 3:2:1, 5) 2.5:2.5:1 and 6) 1:3:2. These media mix ratios are in the form of Field Soil: Manure: Sand order. The details of the methodology was published in Science, Technology and Arts Research Journal [11].

The inorganic nitrogen fertilizer at two levels: without $\mathrm{N}(\mathrm{N}$ at $0 \mathrm{~kg}$ rate ha-1) and with at $25 \mathrm{~kg} \mathrm{~N}$ rate ha- ${ }^{-1}$. Similarly the inorganic phosphorous fertilizer at two levels: without $\mathrm{P}$ (at $0 \mathrm{P} \mathrm{kg} \mathrm{ha}^{-1}$ ) and with $\mathrm{P}$ at $23 \mathrm{~kg} \mathrm{P}$ rate $\mathrm{ha}^{-1}$. All inorganic $\mathrm{P}$ fertilizer were applied once through mixing with the media before filling into the pots and $\mathrm{N}$ were applied twice.

Two levels of $\mathrm{N}$ and $\mathrm{P}$ were combined to give four factorially combined $\mathrm{N}$ and $\mathrm{P}$ treatments, which were again combined with six media mix ratios giving twenty four treatment combinations. The container (pot) size used was $0.17 \mathrm{~m}^{3}$ volume. The treatments were replicated three times. The experiment was laid out as a completely randomized block design in a factorial arrangement and replicated three times per treatment. The variety used was Melakshola tomato variety. This experiment was conducted under rainfed condition during the main season. However, supplementary irrigation was provided for the containerized tomato plants during establishment in the dry spell days and since then left as a rainfed crop.

\section{Drip irrigated tomato}

Similarly the second drip irrigated experiment was conducted during the hot and dry season, combining two factors namely, irrigation scheduling at three levels and nutrient management at five levels were combined. Three irrigation treatments 1) Full irrigation, IRI 2) $80 \%$ ETc, IRII and 3.60\% ETc, IR III were arranged randomly in vertical strips to adjust irrigation depth uniformly along the strips. Integrated nutrient managements 1) rates obtained from field survey (farmers' rate) $\left(\mathrm{N}_{\mathrm{F}} \mathrm{P}_{\mathrm{F}}\right)(\mathrm{N} 185 \mathrm{P} 60)$ [INM-I]), 2) $\mathrm{N}$ and $\mathrm{P}$ rate finding from on station experiment (N75 P50) [INM-II], 3) On station NP rate (N75 P50) +15 tone ha ${ }^{-1}$ (FYM) [INM- III], 4) 15 tone ha-1 (Manure only) [INM-IV] and 5) Zero nitrogen, phosphorous and manure [INM-V] were randomly arranged in horizontal strip plots. The treatments were replicated three times and the experiment was laid down on fifteen total number of plots. Similarly the released Melkasholla tomato variety was used for this experiment; a multipurpose variety, used for both fresh and processing type with semi-determinate growth habit.

\section{Data collection}

Yield data: Yields of tomato (includes both marketable, and 
unmarketable and total fruit yield) were obtained by summing from continuous harvesting until the last harvest.

Physiological parameters: Data on physiological traits such as leaf chlorophyll content was estimated non-destructively using a portable hand held Chlorophyll Meter (Minolta SPAD-502, Konica Minolta Sensing, Inc. Japan). One leaf per plant and five leaves per plot were measured and averaged. The SPAD readings were measured at $90 \mathrm{DAT}$ on fully expanded leaves. The leaf quantum yield measurements were taken using the same SPAD readings similar to leaf chlorophyll content measurement from 9:00 to 11:00 at 90 DAT from fully expanded leaves of 5 plants per plot and averaged. Leaf chlorophyll fluorescence $(\mathrm{Ft})$ was also taken at same time as quantum yield using a hand-held SPAD readings instrument. Samples of five matured top leaves from five branches were taken from compound leaf. Sample leaves were taken from the third to fourth nodal insertion of the compound leaves and assessed for physiological parameters.

\section{Results and Discussions}

The physiological responses of each treatment under each experiment were summarized under the following independent experiments:

\section{Container grown tomato experiment}

Tomato yield: Application of starter N, P or media mix did not bring any combined effect $(P<0.01)$ on the leaf chlorophyll content. However, application of starter $\mathrm{N}$ caused a highly significant $(P<0.01)$ effect on leaf quantum yield and similarly use of media mixtures alone showed a highly significant $(P<0.01)$ effect on the marketable fruit yield of container grown tomato (Table 1).

Marketable fruit yield: Use of combination of starter N and MR showed a significant effect $(P<0.05)$ on the marketable fruit yield of container grown tomato variety Melkasholla (Table 1).

The LSD test at $P=0.05$ probability level showed that the highest marketable fruit yield was recorded from MR3, while the lowest marketable fruit yield was recorded from MR6 (Table 2). There yield increase over the grand mean of MR3 has $149.13 \%$, while MR2 has $136.58 \%$, MR6 has $135.89 \%$, MR1 has $85.98 \%$, MR5 has $69.86 \%$ and MR6 has $22.53 \%$ over the grand mean. Thus MR3 media mixture was found to be the best media mixtures produced highest tomato fruit

\begin{tabular}{|c|c|c|c|c|}
\hline \multirow{2}{*}{$\begin{array}{l}\text { Source of } \\
\text { variations }\end{array}$} & \multirow[t]{2}{*}{ df } & \multicolumn{3}{|c|}{ Mean square values } \\
\hline & & $\begin{array}{l}\text { Marketable } \\
\text { fruit weight }{ }^{a}\end{array}$ & $\begin{array}{l}\text { Unmarketable } \\
\text { fruit weight }^{\text {a }}\end{array}$ & $\begin{array}{l}\text { Total } \\
\text { yield }\end{array}$ \\
\hline Nitrogen (N) & 1 & $0.021 \mathrm{NS}$ & $0.040 \mathrm{NS}$ & $1423546.9 \mathrm{NS}$ \\
\hline Phosphorous (P) & 1 & $0.0002 \mathrm{NS}$ & $0.022 \mathrm{NS}$ & $2036162.0 \mathrm{NS}$ \\
\hline Media mix ratio & 5 & $1.261^{* \star}$ & $0.307^{* *}$ & $156180838.2^{* *}$ \\
\hline $\mathbf{N} \times \mathbf{P}$ & 1 & $0.001 \mathrm{NS}$ & $0.007 \mathrm{NS}$ & $3595668.1 \mathrm{NS}$ \\
\hline NX MR & 5 & $0.052^{\star *}$ & $0.015 \mathrm{NS}$ & $3959058.2 \mathrm{NS}$ \\
\hline P X MR & 5 & $0.010 \mathrm{NS}$ & $0.046 \mathrm{NS}$ & 4604436.1 NS \\
\hline N X P X MR & 5 & $0.051 \mathrm{NS}$ & $0.007 \mathrm{NS}$ & $5105008.3 \mathrm{NS}$ \\
\hline Error & 48 & 0.0160 & 0.0165 & 2873479 \\
\hline Total & 71 & & & \\
\hline $\mathbf{R}^{2}$ & & 0.950 & 0.749 & 0.871 \\
\hline CV (\%) & & 2.423 & 3.741 & 19.330 \\
\hline Root MSE & & 0.088 & 0.128 & 1695.134 \\
\hline
\end{tabular}

Note NS=Indicates non-significant at $\mathrm{P}<0.05$; *significant at $\mathrm{P}<0.05$ and ** significant at $\mathrm{P}<0.01$ probability levels, respectively, $a=$ Transformed data

Table 1: Mean square values of marketable fruit yield, unmarketable fruit and total yield response of container grown tomato under different media mix ratios, $\mathrm{N}$ and $\mathrm{P}$ fertilizer applications planted under rainfed condition.

\begin{tabular}{|c|c|c|c|}
\hline $\begin{array}{l}\text { Media mix } \\
\text { ratio }\end{array}$ & $\begin{array}{c}\text { Marketable fruit } \\
\text { weight }{ }^{\mathrm{a}} \\
\text { (g per plot) }\end{array}$ & $\begin{array}{c}\text { Unmarketable fruit } \\
\text { weight }^{\text {a }} \\
\text { (g per plot) }\end{array}$ & $\begin{array}{l}\text { Total yield per plot } \\
\text { (g) }\end{array}$ \\
\hline MR1 & (4935.9) B & $(1832.4) \mathrm{C}$ & $6768.3 \mathrm{C}$ \\
\hline MR2 & $(7840.4) \mathrm{A}$ & (3528.2) AB & $11368.6 \mathrm{~B}$ \\
\hline MR3 & $(8560.4) A$ & $(4389.3) \mathrm{A}$ & $12949.7 \mathrm{~A}$ \\
\hline MR4 & (7799.5)A & (2987.8) B & 10787.2 B \\
\hline MR5 & (4010.3) C & (3559.2) AB & $7569.4 \mathrm{C}$ \\
\hline MR6 & $(1293.8) \mathrm{D}$ & $(1878.4) \mathrm{C}$ & $3172.2 \mathrm{D}$ \\
\hline Mean & 5740.021 & (3029.201) & 8769.22 \\
\hline LSD (0.05) & 30.113 & 0.1057 & 1560 \\
\hline \multicolumn{4}{|c|}{ Nitrogen (kg ha-1) } \\
\hline 0 & $(5747.2)$ & (2881.4) & 8628.6 \\
\hline 25 & $(5732.8)$ & (3177.0) & 8909.8 \\
\hline \multicolumn{4}{|l|}{ Mean } \\
\hline LSD (0.05) & NS & 0.0422 & NS \\
\hline \multicolumn{4}{|l|}{$\mathbf{P}\left(\mathbf{k g ~ h a}^{-1}\right)$} \\
\hline 0 & $(5684.3)$ & (2916.8) & 8601.1 \\
\hline 23 & (5795.7) & $(3141.7)$ & 8937.4 \\
\hline \multicolumn{4}{|l|}{ Mean } \\
\hline LSD (0.05) & NS & NS & NS \\
\hline
\end{tabular}

*= Average of three replications. Means followed in a column with the same letters are not significantly different using LSD at $P=0.05$ level of significance respectively; $a$ = Data were transformed, means in brackets are original data

Table 2: Mean response values of marketable fruit weight, unmarketable fruit weight total yield response of tomato planted under different media mixes, $\mathrm{N}$ and $\mathrm{P}$ application rates under rainfed growing conditions*.

yield. The tomato plants produced the highest marketable fruit yield in the medium that had 4:1:1 (60\% soil: $15 \%$ : farmyard manure and $15 \%$ sand). The sole soil medium treatment (check) in this experiment suffered from moisture stress in the afternoons at the time of dry spells, which was disastrous during the critical growth stages prior, at and after flowering, which caused reduced growth and yield.

\section{Total fruit yield:}

Use of media mix ratio showed a highly significant effect $(P<0.01)$ on the total fruit yield of container grown tomato (Table 1). The LSD test at $P=0.05$ probability level showed that MR3 yielded the highest total fruit yield while MR6 gave the lowest total fruit yield (Table 2). It is concluded from this experiment that use of the ratio of 4 field top soil: 1 manure: 1 sand order gave the highest fruit yield for container grown tomato around Melkassa during the rainy season; increasing the ratio of manure beyond this proportion reduced the tomato fruit yield.

\section{Unmarketable fruit yield}

Similar to marketable fruit, use of media mixtures had highly significant $(P<0.01)$ influence on the unmarketable fruit yield of container grown rainfed tomato (Table 1). The highest unmarketable fruit yield record was obtained from MR3 treatment while the lowest unmarketable fruit yield was obtained from the check and (Table 2).

\section{Physiological responses of tomato}

Application of starter N, P or media mix brought variable effects on the physiological responses of container grown tomato.

\section{Leaf quantum yield}

Among the physiological responses, leaf quantum yield, application of starter $\mathrm{N}$ caused a highly significant $(P<0.01)$ effect on leaf quantum yield of container grown tomato (Table 3 ). The LSD test at $P=0.05$ probability level indicated that the highest leaf quantum yield was obtained from application of starter $\mathrm{N}$ and the lowest leaf quantum yield was from the check (Table 3 ). This would imply the leaves of 


\begin{tabular}{|c|c|c|c|c|}
\hline \multirow{2}{*}{$\begin{array}{l}\text { Source of } \\
\text { Variations }\end{array}$} & \multirow[b]{2}{*}{ df } & \multicolumn{3}{|c|}{ Mean square values } \\
\hline & & $\begin{array}{l}\text { Leaf chlorophyll } \\
\text { fluorescence }\end{array}$ & $\begin{array}{l}\text { Leaf quantum } \\
\text { yield }\end{array}$ & $\begin{array}{l}\text { Leaf chlorophyll } \\
\text { content }\end{array}$ \\
\hline Nitrogen (N) & 1 & 2804.17 NS & $0.021^{* \star}$ & 387.811NS \\
\hline Phosphorous (P) & 1 & $288.00 \mathrm{NS}$ & $0.0008 \mathrm{NS}$ & $0.623 \mathrm{NS}$ \\
\hline MR & 5 & 1296.98 NS & $0.005 \mathrm{NS}$ & 21.617 NS \\
\hline NXP & 1 & $1104.50 \mathrm{NS}$ & $0.0001 \mathrm{NS}$ & $1.201 \mathrm{NS}$ \\
\hline NX MR & 5 & $381.50 \mathrm{NS}$ & $0.005 \mathrm{NS}$ & $25.532 \mathrm{NS}$ \\
\hline PXMR & 5 & 707.422 NS & 0.001 NS & 7.448 NS \\
\hline N X P X MR & 5 & 353.011 NS & $0.0024 \mathrm{NS}$ & $16.746 \mathrm{NS}$ \\
\hline Error & 48 & 635.595 & 0.0033 & 23.297 \\
\hline Total & 71 & & & \\
\hline $\mathbf{R}^{2}$ & & 0.419 & 0.448 & 0.419 \\
\hline CV (\%) & & 8.438 & 10.126 & 11.812 \\
\hline Root MSE & & 25.211 & 0.057 & 4.826 \\
\hline
\end{tabular}

NS $=$ Indicates non-significant at $P<0.05$; * significant at $P<0.05$ and ${ }^{* *}$ significant at $\mathrm{P}<0.01$ probability levels

Table 3: Mean square values of physiological, yield and early blight response of container grown tomato under different media mix ratios, $\mathrm{N}$ and $\mathrm{P}$ fertilizer applications planted under rainfed condition.

tomato plant fertilized with $\mathrm{N}$ nutrient would indicates that every photon absorbed would contributes to the photosynthesis process and vice versa. However under this experiment use of application of starter $\mathrm{P}$ and use of media mix ratio did not bring any significant difference on the leaf quantum yield.

\section{Leaf chlorophyll content}

Use of starter $\mathrm{N}$, starter $\mathrm{P}$ and use of media mix rations either separately or in a combined ways did not affect the tomato leaf chlorophyll content.

\section{Leaf chlorophyll fluorescence}

The results container grown tomato indicated that use of media mixtures, starter $\mathrm{N}$ and starter $\mathrm{P}$ either in a combined form or separately, did not affect tomato leaf fluorescence at $5 \%$ probability level (Table 3).

In general, tomatoes grown under different media mix ratios and supplementary $\mathrm{N}$ and $\mathrm{P}$ fertilizers actually faced two major problems that limited their growth and development; one problem was root confinement and another was the intermittent moisture stress as they were grown under rainfed conditions. Tomato plants grown in field were less affected by low moisture stress during the dry spell as compared to container grown tomato; probably, field grown tomato plant roots explored more volume of soil.

Treatments with FYM were found to be less stressed during dry spells as compared to the check plot, indicating that FYM improves water holding characteristics of the media. In addition, the media containing FYM were less affected by crusting and sealing as this problem was observed in the greenhouse experiment, probably due to association with soil structure, low organic matter content of the topsoil. This is probably because farmyard manure increases organic matter content of the media, which is food for soil biota that enhance the availability of nutrients such as phosphate through increased solubilization. In addition, the organic matter holds moisture like a sponge, avoiding stress during dry days throughout the growth period of tomato plant.

\section{Drip irrigated tomato experiment}

\section{Tomato yield}

\section{Marketable fruit yield}

Use of various irrigation depths brought a significant $(P<0.01)$ effect on the marketable yield of tomato (Table 4). The mean separation at $P=0.05$ probability level indicated that the highest marketable fruit yield was recorded in response to full irrigation, while the lowest marketable fruit yield was recorded from $60 \%$ of full irrigation (Table 5); similar results were reported by Kirnak et al. where full water supply significantly increased fruit yield of eggplant [12]. However application of integrated nutrient management (INM) did not bring about any significant $(P<0.05)$ difference on marketable fruit yield probably the fertility status of the soil was good (the details of soil analysis was published in African Journal of Agricultural Research.

\section{Unmarketable fruit yield}

Application of irrigation did not bring significant difference $(P<0.05)$ on unmarketable fruit yield of tomato (Table 4$)$.

\section{Total fruit yield}

Use of irrigation depth had a significant $(P<0.05)$ effect on total fruit yield; the highest fresh fruit yield was obtained from full irrigation and the lowest was obtained from $60 \%$ irrigation water with saving of $40 \%$ of irrigation water (Table 5 ). Thus, the fresh fruit yield obtained from fully irrigated tomato plot exceeded the fresh fruit yield obtained from tomato plot irrigated with only $60 \%$ of full irrigation water by $62.8 \%$. The results showed that with decrease in the depth of irrigation, there was a decrease in total fruit yield in tomato due to reduced uptake of water (Table 5). The result of this study corroborate that of Muchovej who reported that high quality and yield of vegetable crops are directly associated with proper water management. They also found that the fresh fruit yields of Melkasholla variety was reduced under deficit irrigation level. Similar findings were reported by Kirnak et al. where egg plants grown under high water stress had less fruit yield and quality than those in the control treatment [12]. Consistent with the results of this study Kirnak et al. also found that water stress in the container grown eggplants produced a very significant reduction in both dry biomass, they found that eggplant fruit yield was reduced by up to $68 \%$ in the water stressed plants compared with unstressed plants [12]

\begin{tabular}{|c|c|c|c|}
\hline $\begin{array}{l}\text { Media mix } \\
\quad \text { ratio }\end{array}$ & $\begin{array}{l}\text { Leaf chlorophyll } \\
\text { fluorescence }\end{array}$ & $\begin{array}{c}\text { Leaf quantum } \\
\text { yield }\end{array}$ & $\begin{array}{l}\text { Leaf chlorophyll } \\
\text { content }\end{array}$ \\
\hline MR1 & 308.11 & $0.57122 \mathrm{AB}$ & 39.317 \\
\hline MR2 & 290.17 & $0.58801 \mathrm{~A}$ & 39.600 \\
\hline MR3 & 289.86 & 0.53793 B & 42.408 \\
\hline MR4 & 288.03 & $0.54971 \mathrm{AB}$ & 40.525 \\
\hline MR5 & 310.14 & $0.57329 \mathrm{AB}$ & 40.858 \\
\hline MR6 & 306.19 & $0.59222 \mathrm{~A}$ & 42.450 \\
\hline Mean & 298.750 & 0.568 & 40.859 \\
\hline LSD (0.05) & NS & 0.0473 & NS \\
\hline \multicolumn{4}{|c|}{ Nitrogen (kg ha-1) } \\
\hline 0 & 292.509 & $0.55160 \mathrm{~B}$ & $38.539 \mathrm{~B}$ \\
\hline 25 & 304.991 & $0.58586 \mathrm{~A}$ & $43.181 \mathrm{~A}$ \\
\hline \multicolumn{4}{|l|}{ Mean } \\
\hline LSD (0.05) & NS & 0.0273 & 2.29 \\
\hline \multicolumn{4}{|l|}{$\begin{array}{l}\text { Phosphorous } \\
\left(\mathbf{k g ~ h a}^{-1}\right)\end{array}$} \\
\hline 0 & 296.750 & 0.56525 & 40.953 \\
\hline 23 & 300.750 & 0.57220 & 40.767 \\
\hline \multicolumn{4}{|l|}{ Mean } \\
\hline LSD (0.05) & NS & NS & NS \\
\hline
\end{tabular}

* = Average of three replications. Means followed in a column with the same letters are not significantly different using LSD at $P=0.05$ level of significance respectively; $\mathrm{a}=$ Data were transformed, means in brackets are original data

Table 4: Mean response values of yield and selected physiological response of tomato planted under different media mixes, $\mathrm{N}$ and $\mathrm{P}$ application rates under rainfed growing conditions. 
They also reported that restricted water supply for tomato can suppress new leaf development, resulting in a shortened yield formation period. Similar findings were reported by Cetin that water stress significantly reduced final yield of field-grown sweet pepper. Similar findings were obtained where increasing irrigation increased total tomato fruit yield.

Irrigation positively influenced tomato productivity; the result was attributed to the increase in the number of berries per plant and the fruit average weight as irrigation increased. The authors concluded that the total yield and marketable tomato yields were decreased significantly as the deficit level was increased. The reduction in total yield of tomato with an increased amount of water stress level of this test was consistent with previous work conducted on tomato and other crops such as cotton as reported.

\section{Physiological responses of tomato to irrigation regimes}

\section{Leaf chlorophyll fluorescence}

The results of variance analysis indicated that applying various irrigation depths did not bring any significant effect on tomato leaf chlorophyll fluorescence of tomato at all (Table 5).

However, the results of chlorophyll fluorescence measurement indicated that as irrigation depth increased the chlorophyll fluorescence was reduced (Figure 1). Based on the review of Maxwell and Johnson, light energy absorbed by chlorophyll molecules in a leaf can undergo one of three fates: it can be used to drive photosynthesis (photochemistry), excess energy can be dissipated as heat or it can be re-emitted as light-chlorophyll fluorescence [7]. These three processes occur in competition, such that any increase in the efficiency of one will result in a decrease in the yield of the other two. The results from this experiment showed that as irrigation depth increased, the portion of light energy absorbed by chlorophyll molecules in a leaf can undergo to drive photosynthesis (photochemistry) performance would be increased so that yield of the tomato plant increased. On the other hand deficit irrigation increased leaf chlorophyll fluorescence of tomato

\begin{tabular}{|c|c|c|c|}
\hline $\begin{array}{l}\text { Irrigation } \\
\text { regimes }\end{array}$ & $\begin{array}{l}\text { Marketable } \\
\text { fruit (t ha-1) }\end{array}$ & $\begin{array}{c}\text { Unmarketable } \\
\text { yield }\left(\mathrm{t} \mathrm{ha}^{-1}\right)\end{array}$ & $\begin{array}{l}\text { Total fruit } \\
\text { yield }\left(t \text { ha }^{-1}\right)\end{array}$ \\
\hline IR I (100\% ETc) (Full irrigation) & $63.63 \mathrm{~A}$ & 18.267 & $81.902 \mathrm{~A}$ \\
\hline IR II (80\% ETc) & $33.83 \mathrm{~B}$ & 22.413 & $56.250 \mathrm{~B}$ \\
\hline IR III (60 \% ETc) & $27.82 \mathrm{~B}$ & 23.062 & $50.868 \mathrm{C}$ \\
\hline Mean & 41.765 & 20.813 & 62.916 \\
\hline LSD (0.05) & 9.712 & NS & 5.689 \\
\hline
\end{tabular}

* = Average of three replications. Means within each column with different letters are significantly different at LSD at $P=0.05$ level of probability

Table 5: Mean values of various irrigation regimes on marketable, unmarketable and total fruit yield of tomato grown under drip irrigated condition.

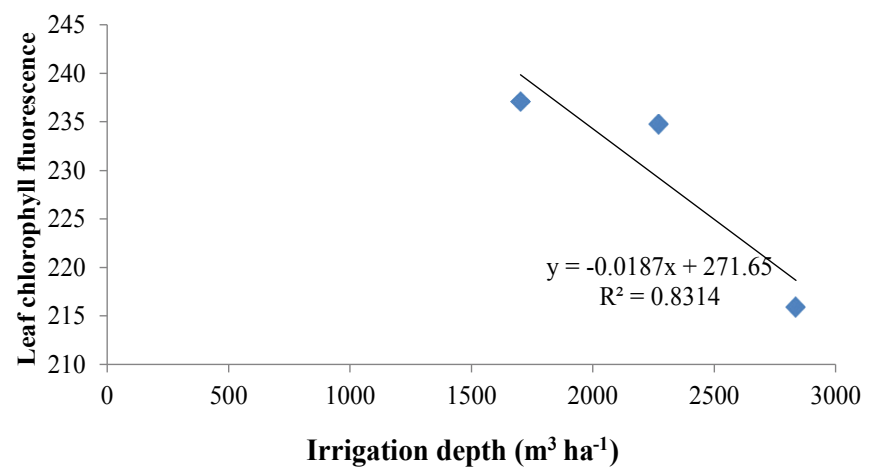

Figure 1: Graphical relationship of leaf chlorophylls fluorescence responses of tomato as a function of irrigation regimes. probably suggesting much light is not used in the photosynthesis performance.

\section{Leaf chlorophyll content}

Applying various irrigation depth significantly $(P<0.01)$ affected the tomato leaf chlorophyll content (Table 5). The mean separation indicated that the highest irrigation level increased leaf chlorophyll content and lowest irrigation depth reduced leaf chlorophyll content (Table 5). This would indicate that water availability in the soil would contribute to the N nutrient uptake [13-17].

The regression function analyze indicated that as irrigation depth increased, the leaf chlorophyll content increased linearly. The result further indicated that as irrigation depth increased the leaf chlorophyll content found to be increased in power function $\mathrm{R}^{2}=82 \%$, further indicating the tomato plant more nutrient $\mathrm{N}$ uptake due to moisture availability (Figure 2). Similar findings were reported by Kirnak et al. where water stress resulted in significant decreases in chlorophyll content of egg plants [12].

The larger the irrigation depth the greener tomato plant leaf became; this correspondingly contributed to better growth and development and further yield. Similar results were found by Kirnak et al. who reported that water stress in the container grown eggplants produced a very significant reduction in total chlorophyll content [12]

The regression function analyze indicated that as irrigation depth increased, the leaf chlorophyll content was found to be increased in power function $\left(R^{2}=82 \%\right)$. Similar findings were reported by Kirnak et al. where water stress resulted in significant decreases in chlorophyll content of egg plants [12].

\section{Leaf quantum yield}

The results of this experiment shown that irrigation depths did not bring any significant effect on tomato leaf quantum yield (Table 5).

\section{Stomatal conductance}

The irrigation depth brought significant $(P<0.01)$ effect on the stomatal conductance of tomato plant (Table 5). As irrigation depth decreased, leaf stomatal conductance was highly reduced [18]. The leaf stomatal conductance was the highest for full irrigation, and the lowest for the lowest irrigation depth as indicated in Table 6. This indicates that under low moisture conditions tomato leaves had low stomatal conductance that contributed to low $\mathrm{CO}_{2}$ assimilation and further low corresponding fruit yield $[19,20]$. Well-watered eggplant had high transpiration rate than stressed plants that would contributed to higher fruit yield [12]. They found that transpiration rate gradually decreased

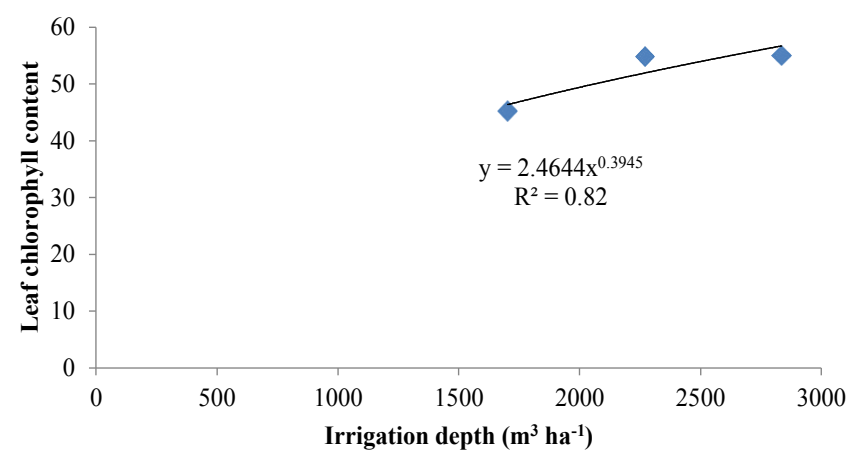

Figure 2: Graphical relationship of leaf chlorophyll content responses of tomato as a function of irrigation regimes. 
with increasing the incidence of water stress. Delfine et al. also found that water stress rapidly affected stomatal conductance of field-grown sweet pepper [13].

Figure 3 indicates that at higher irrigation regimes, there would be higher stomatal conductance with regression function linearly at $\mathrm{R}^{2}$ $=90 \%$, relationship. Low stomatal conductance indicates significant stomatal closure associated with reduced transpiration Taiz and Zeiger and low dry matter production [5]. Low stomatal conductance is related to low water supply to the stomata, which implies relatively dried conditions in the root zone Table 7 . Mild water stress does usually affect both leaf photosynthesis and stomatal conductance [5].

\section{Summery and Conclusions}

Field experiments were conducted at Melkassa Agricultural Research centre to study tomato fruit yield such as marketable, unmarketable and total fruit yield and some physiological response such as quantum yield, leaf chlorophyll content, leaf fluorescence and stomatal conductance of tomato. The first experiment was conducted with container grown tomato during rainy season while the second field

\begin{tabular}{|l|c|c|c|c|c|}
\hline \multirow{2}{*}{$\begin{array}{l}\text { Source of } \\
\text { variations }\end{array}$} & df & \multicolumn{4}{|c|}{ Mean square values } \\
\cline { 3 - 6 } & & $\begin{array}{c}\text { Leaf } \\
\text { fluorescence }\end{array}$ & $\begin{array}{c}\text { Leaf } \\
\text { quantum } \\
\text { yield }\end{array}$ & $\begin{array}{c}\text { Leaf } \\
\text { chlorophyll } \\
\text { content }\end{array}$ & $\begin{array}{c}\text { Stomatal } \\
\text { conductance }\end{array}$ \\
\hline Irrigation & 2 & $2025.41 \mathrm{NS}$ & $0.00153 \mathrm{NS}$ & $466.172^{* *}$ & $22349.2^{* *}$ \\
\hline Error & 4 & 1367.90 & 0.00783 & 3.216 & 403.40 \\
\hline CV & & 16.13 & 16.57 & 3.47 & 15.12 \\
\hline
\end{tabular}

Note NS $=$ Indicates non-significant at $\mathrm{P}<0.05$; ${ }^{*}$ significant at $\mathrm{P}<0.05$ and ** significant at $P<0.01$ probability levels

Table 6: Mean square values of physiological and yield response of tomato as influenced by integrated nutrient managements and application of various moisture regimes.

\begin{tabular}{|l|c|c|c|c|}
\hline \multicolumn{1}{|c|}{$\begin{array}{c}\text { Irrigation } \\
\text { regimes }\end{array}$} & $\begin{array}{c}\text { Leaf } \\
\text { quantum } \\
\text { yield }\end{array}$ & $\begin{array}{c}\text { Leaf } \\
\text { chlorophyll } \\
\text { content }\end{array}$ & $\begin{array}{c}\text { Stomatal } \\
\text { conductance }\end{array}$ & $\begin{array}{c}\text { Leaf } \\
\text { chlorophyll } \\
\text { fluorescence }\end{array}$ \\
\hline $\begin{array}{l}\text { IR I (100\% ETc, Full } \\
\text { irrigation) }\end{array}$ & 0.52267 & $55.02 \mathrm{~A}$ & $176.74 \mathrm{~A}$ & 215.89 \\
\hline IR II (80\% ETc) & 0.53733 & $54.88 \mathrm{~A}$ & $117.29 \mathrm{~B}$ & 234.73 \\
\hline IR III (60\% ETc) & 0.54200 & $45.30 \mathrm{~B}$ & $104.36 \mathrm{~B}$ & 237.09 \\
\hline Mean & 0.534 & 51.737 & 132.80 & 229.23 \\
\hline LSD (0.05) & NS & 1.818 & 20.362 & NS \\
\hline
\end{tabular}

$=$ Average of three replications. Means within each column with different letters are significantly different at LSD at $P=0.05$ level of probability

Table 7: Mean values of yield and physiological response of tomato grown under various irrigation regimes and integrated nutrient management practices.

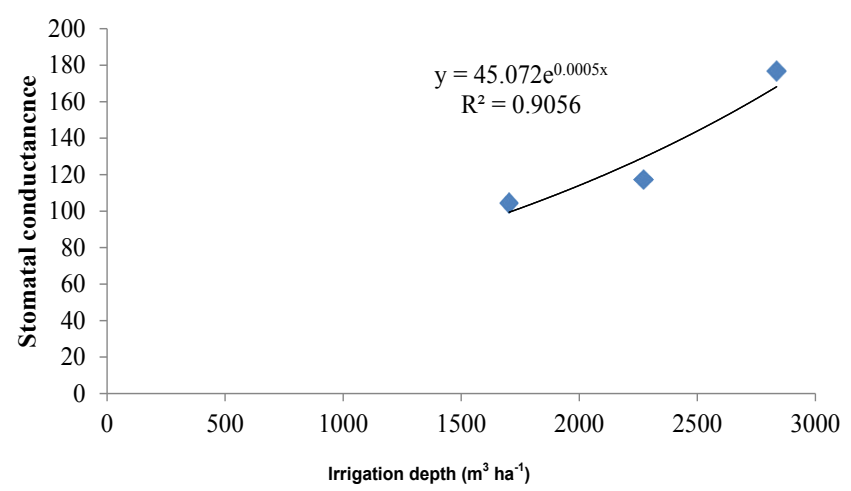

Figure 3: Graphical relationship of leaf stomatal conductance responses of tomato as a function of irrigation regimes. experiment was conducted under drip irrigation during hot dry season; the treatments consisted of two levels of $\mathrm{N}\left(0\right.$ and $\left.25 \mathrm{~kg} \mathrm{~N} \mathrm{ha}^{-1}\right)$, and two levels of $\mathrm{P}\left(0\right.$ and $\left.23 \mathrm{~kg} \mathrm{P} \mathrm{ha} \mathrm{a}^{-1}\right)$ fertilizers and with six media mix ratios. For the second drip irrigated experiment, factorial combinations of five levels of nutrient management and of three levels of daily irrigation treatments such as full irrigation, $80 \%$ and $60 \%$ of daily ETc irrigation regimes on the strip plot design was used irrigation as vertical and nutrient management laid as horizontal strip. The results of container grown experiment indicated that use of combination of starter $\mathrm{N}$ and MR showed a significant effect on the marketable fruit yield, similarly use of media mixtures had highly significant influence on the unmarketable fruit yield and finally use of media mix ratio showed a highly significant effect on the total fruit yield of container grown tomato. Media mix ratio 3 (4:1:1, in the form of field soil: manure: sand order) yielded the highest total fruit yield while MR6 (1:3:2) gave the lowest total fruit yield. Application of starter N, P or media mix did not bring any combined effect on the leaf chlorophyll content. However, application of starter $\mathrm{N}$ caused a highly significant effect on leaf quantum yield. The results of drip irrigated experiment indicated that use of various irrigation depths brought a significant effect on the marketable yield of tomato; highest fruit yield was recorded in response to full irrigation, while the lowest marketable fruit yield was recorded from least irrigation depth. Irrigation depth significantly affected the tomato leaf chlorophyll content and the stomatal conductance of tomato plant. As irrigation depth decreased, leaf stomatal conductance was highly reduced. The leaf stomatal conductance was the highest for full irrigation, and the lowest for the lowest irrigation depth. Thus use of these sensors should be further fine-tuned for the field management applications.

\section{References}

1. Etissa E (2014) Irrigation and Nutrient Management Studies on Vegetable Crops with Particular Reference to Tomato (Lycopersicum esculentum M.) in the Central Rift Valley of Ethiopia. Electronic Thesis and Dissertation, Haramaya University. p: 310

2. Etissa E, Dechassa N, Alamirew T, Alemayehu Y, Dessalegne L (2014) Irrigation Water Management Practices in Small Scale Household Vegetable Crops Production System: The Case of the Central Rift Valley Area of Ethiopia. Sci Technol Arts Res J 3: 74-83.

3. Etissa E, Dechassa N, Alamirew T, Alemayehu Y, Desalegne L (2013) Household Fertilizers Use and Soil Fertility Management Practices in Vegetable Crops Production: The Case of Central Rift Valley of Ethiopia. Sci Technol Arts Res J 2: 47-55.

4. Misra AN, Misra M, Singh R (2012) Chlorophyll Fluorescence in Plant Biology In: Misra AN (ed.) Biophysics. pp: 171-192.

5. Taiz L, Eduardo Z (2003) Plant Physiology.

6. Strasser RJ, Srivastava A, Tsimilli-Michael M (2000) The Fluorescence Transient as a Tool to Characterize and Screen Photosynthetic Samples. In: M Yunus, U Pathre, P Mohanty (eds.) Probing Photosynthesis: Mechanism, Regulation and Adaptation. pp: 445-483.

7. Maxwell K, Johnson GN (2000) Chlorophyll Fluorescence-A Practical Guide. J Exp Bot 51: 659-668.

8. Falkowski PG, Raven JA (2007) Aquatic Photosynthesis ( $2^{\text {nd }}$ edn.). Princeton University Press, Princeton. p: 484

9. Roberto P, Moya I, Goulas Y, Jacquemoud S (2008) Chlorophyll Fluorescence Emission Spectrum inside a Leaf. Photochem Photobiol Sci 7: 498-502.

10. Vu Joseph CV, Allen LH, Gallo-Meagher M (2001) Crop Plant Responses to Rising $\mathrm{CO}_{2}$ and Climate Change. In: Pessarakli M (ed.) Handbook of Plant and Crop Physiology. CRC Press.

11. Etissa E, Dechassa N, Alemayhu Y (2015) Effect of Growth Media, Starter N and $\mathrm{P}$ Fertilizers on Growth and Yield of Tomato under Rainfed Condition in the Central Rift Valley of Ethiopia. Sci Technol Arts Res J 4: 23-31. 
Citation: Etissa E, Dechassa N, Alemayehu Y (2016) Yield and Physiological Response of Tomato to Various Nutrient Managements under Container Grown and Drip Irrigated Conditions. Irrigat Drainage Sys Eng 5: 171. doi: 10.4172/2168-9768.1000171

12. Kirnak H, Cengiz K, Ismail T, David H (2001) The Influence of Water Deficit on Vegetative Growth, Physiology, Fruit Yield and Quality in Eggplants. Bulg J Plant Physiol 27: 34-46

13. Delfine S, Alvino A, Loreto F, Centritto M, Santarelli G (2000) Effects of Water Stress on the Yield and Photosynthesis of Field-grown Sweet Pepper (Capsicum annuum L.). Crops Acta Hort.

14. Strasser RJ, Tsimilli-Michael M, Srivastava A (2004) Analysis of the Chlorophyll Fluorescence Transient. Advances in Photosynthesis and Respiration 41: 321-362.

15. Govindjee (2004) Chlorophyll a Fluorescence: A Bit of Basics and History. Advances in Photosynthesis and Respiration 19: 1-41.

16. Allen RG, Pereira LS, Raes D, Smith M (1998) Crop Evapotranspiration (Guidelines for Computing Crop Water Requirements). FAO. Irrigation and Drainage Paper No 56, Italy.
17. Etissa E, Dechassa N, Alamirew T, Alemayehu Y, Dessalegne L (2014c) Growth and Physiological Response of Tomato to Various Irrigation Regimes and Integrated Nutrient Management Practices. African Journal of Agricultura Research 9: 1484-1489.

18. Etissa E, Dechassa N, Alamirew T, Alemayehu Y, Dessalegne L (2013b) Growth and Yield Components of Tomato as Influenced by Nitrogen and Phosphorus Fertilizer Application in Different Growing Seasons. Ethiopian Journal of Agricultural Science 25: 57-77.

19. Etissa E, Dechassa N, Alamirew T, Alemayehu Y, Dessalegne L (2014) Growth and Physiological Response of Tomato to Various Irrigation Regimes and Integrated Nutrient Management Practices. African Journal of Agricultural Research 9: 1484-1489.

20. Jones JB (2008) Tomato Plant Culture: In the Field, Greenhouse and Home Garden. CRC Press.
Citation: Etissa E, Dechassa N, Alemayehu Y (2016) Yield and Physiologica Response of Tomato to Various Nutrient Managements under Containe Grown and Drip Irrigated Conditions. Irrigat Drainage Sys Eng 5: 171. doi: 10.4172/2168-9768.1000171 